\title{
Bioactivity and Chemical Composition of the Essential oil of Tea Tree (Melaleuca alternifolia)
}

\author{
Seun-Ah Yang, Sang-Kyung Jeon ${ }^{1}$, Eun-Jung Lee', Nam-Kyung $\mathrm{Im}^{1}$, Ji-Young Jung ${ }^{2}$ and In-Seon Lee *
}

The Center for Traditional Microorganism Resources, Keimyung University, Daegu 704-701, Korea

${ }^{1}$ Department of Food Science and Technology, Keimyung University, Daegu 704-701, Korea

${ }^{2}$ MENTech Co., Ltd., Daegu 704-948, Korea

Received October 30, 2008 / Accepted December 11, 2008

\begin{abstract}
The essential oil of tea tree (Melaleuca alternifolia) is widely used in traditional Australian medicine for skin lesions and infected injuries. In the present study, we investigated the chemical composition, cytotoxicity and its biological activities. The composition of the oil was analyzed by GC-MS. $\beta$ Terpinene $(20.87 \%)$, a-pinene $(17.60 \%)$, p-cymene $(11.23 \%), 3$-carene $(10.40 \%)$, trans-anethole $(8.47 \%)$ and limonene $(4.65 \%)$ were the major components in the oil. The results tested by MTT assay indicated that the oil showed no cytotoxic effect, at concentrations up to $5 \%$, for less than $3 \mathrm{~h}$. The antiradical capacity was evaluated by measuring the scavenging activity of the essential oil on the 2,20-diphenylpicrylhydrazyl (DPPH) and 2,2'-azino-bis 3-ethyl benzothiazoline-6-sulfonic acid (ABTS) radicals. The oil was able to reduce the both radicals dose-dependently, and the concentration required for $50 \%$ reduction $\left(\mathrm{RC}_{50}\right)$ against ABTS radicals $(1.6 \pm 0.02 \%)$ was slightly lower than DPPH radicals $(2.6 \pm 0.29 \%)$. The direct contact and vapor-phase antibacterial activity of the oil were also evaluated using disc diffusion method against Staphylococcus aureus, Streptococcus mutans, Listeria monocytogenes, Acinetobacter baumannii, Escherichia coli, and Vibrio parahaemolyticus. All the Gram-negative bacterial strains tested showed more sensibility to the oil than the Gram-positive strains when compare to the effect of gentamycin. On the other hand, the vapor phase of the essential oil against $S$. aureus exhibited strongest inhibitory effect.
\end{abstract}

Key words : Tea tree essential oil, Melaleuca alternifolia, antiradical, antibacterial, cytotoxicity

\section{Introduction}

Tea tree essential oil extracted from Australian Melaleuca alterifolia by steam distillation method has been studied extensively for their antimicrobial properties against different type of bacteria and fungi $[9,22,23]$. Tea tree oil has been reported to have antibacterial activity against all 66 isolates of methicillin-resistant Staphylococcus aureus (MRSA) using both disc diffusion and broth microdilution methods [2]. These methods required modifications to enable the oils to be solubilized and the broths clarified to enable reliable quantitative detection of bacterial growth or inhibition [3]. The antimicrobial activities of eight components of tea tree oil have been tested and 1-terpinen-4-ol was found to be active against $P$. aeruginosa, Candida albicans, E.coli and S. aureus [3]. Linalool and the $\alpha$-terpineols such as $\alpha$-terpinene, $\gamma$ terpinene, $\alpha$-terpineol and terpinolene were active against Candida albicans, E.coli and S. aureus while p-cymene ex-

*Corresponding author

Tel : +82-53-580-6449, Fax : +82-53-580-6447

E-mail : seunahy@kmu.ac.kr hibited no antimicrobial activity. The oil consists of a mixture of monoterpenoids [1] but the known compositions vary depending on genetical and environmental conditions [17]. Moreover, the biological activity has been shown to be related to terpinen-4-ol, and the oil with lower terpinen-4-ol concentrations lack antimicrobial activity so far $[3,18]$. Tea tree oil is widely known for its germicidal effect [4] and it is used for skin products, wound care, cosmetics and as natural antiseptic agents [7]. It also used as carminatives and in the treatment of several ailments [6] and essential oils including tea tree oil are found in many products like flavors, soaps, liniments, and dentistry products.

The present study was set up to screen the cytotoxicity, chemical composition, antiradical and antibacterial activities of commercially available and popular Australian tea tree oil obtained from reliable company to evaluate its potential for industrial application such as foods, cosmetics, etc.

\section{Materials and Methods}

\section{Chemicals}

Pure standard substances of $\alpha$-pinene and $\gamma$-terpinene 
were purchased from Sigma-Aldrich (Sigma, St. Louis, MO, USA) and limonene, $\beta$-pinene, $\alpha$-terpinene were from Tokyo Chemical Industry Co., Ltd. (TCI, Tokyo, Japan). Ascorbic acid was obtained from Shinyo chemical Co. Ltd. Butylated Hydroxytoluene (BHT), butylated Hydroxyanisole (BHA), 2,20-diphenylpicrylhydrazyl (DPPH), 2,2'-azino-bis 3-ethyl benzothiazoline-6-sulfonic acid (ABTS), Earle's basal salt solution (EBSS), trypsin solution, 3-(4,5-dimethylthiazol-2-yl)2,5-diphenyl tetrazolium bromide (MTT), trolox were obtained from Sigma Chemical Co. (St Louis, MO). Fetal bovine serum (FBS) and Dulbecco's modified eagle medium (DMEM) were from Gibco BRL (NY, USA).

\section{Essential oil}

Commercial tea tree essential oil which extracted by steam distillation from leaves of Melaleuca alterifolia, a species of northern New South Wales, Australia was obtained from Skinmate (Puchon, Gyeonggi-do, Korea). It was stored in glass vials with Teflon sealed caps at $4^{\circ} \mathrm{C}$ in the absence of light.

\section{GC-MS analysis}

GC-MS spectrometry analysis of the oils was performed on a GC/MSD Polaris $Q$ (Thermo Finnigan, USA) instrument. The detailed parameters were shown in Table 2. Briefly, HP5MS capillary column $(30 \mathrm{~m} \times 0.25 \mathrm{~mm}$ i.d., film thickness $0.32 \mu \mathrm{m}$ ) was used with the following temperature program: initial oven temperature, $40^{\circ} \mathrm{C}$ for $5 \mathrm{~min}$; then gradient of $4^{\circ} \mathrm{C} / \mathrm{min}$ to $200^{\circ} \mathrm{C}$, held $5 \mathrm{~min}$; followed by a gradient of $20^{\circ} \mathrm{C} / \mathrm{min}$ to $280^{\circ} \mathrm{C}$, held $10 \mathrm{~min}$. Injector line temperatures was set at $260^{\circ} \mathrm{C}$, and a split ratio of $10: 1$ was applied. Helium was used as the carrier gas at a flow rate of $1.0 \mathrm{ml} / \mathrm{min}$. The interface temperature was $280^{\circ} \mathrm{C}$. For GC-MS detection, electron ionization system with ionization system energy $70 \mathrm{eV}$ was used. Total ion current (TIC) chromatograms were recorded in a mass range of 30-350 amu. The components were identified by comparison of their relative retention times with authentic substances and mass spectra with NIST, WILLY library data of the GC-MS system and literature data.

\section{Cell culture and treatment}

Skin CCD-986SK human fibroblast cells were obtained from Korean cell line bank (Seoul, Korea). Cells were cultured at $37^{\circ} \mathrm{C}$ in the presence of $5 \% \mathrm{CO}_{2}$ in DMEM supplemented with $10 \%$ FBS. For the treatment, the oil was diluted with a culture medium. In every experiment, cells in negative control group were treated with the same concentration of dimethyl sulfoxide (DMSO) $(0.1 \%)$ as contained in the tea tree oil-treated group.

\section{Determination of cell viability}

Cell viability that was assessed by the MTT staining assay [25] based on the reduction of a MTT into formazan dye by active mitochondria reflects the cytotoxicity of tea tree oil. CCD-986SK cells were seeded at a density of 10,000 cells/well in 96-well microplate. The next day, cells were treated with tea tree oil at $37^{\circ} \mathrm{C}$ for $48 \mathrm{hr}$. At the end of culture, $100 \mu$ of MTT $(5 \mathrm{mg} / \mathrm{ml})$ were added to each well, and plates were incubated at $37^{\circ} \mathrm{C}$ for $4 \mathrm{hr}$. One hundred microliters DMSO were added to each well to dissolve the cells. The plates were kept at room temperature for $5 \mathrm{~min}$ and the absorbance was measured at $550 \mathrm{~nm}$ using a multiwell spectrophotometer (Molecular Devices, Sunnyvale, CA).

\section{Bacterial cultures}

The bacterial strains used in this study are listed in Table 3. The S. aureus were grown in tryptic soy agar broth (Becton Dickinson, USA), and the S. mutans and L. monocytogenes were grown in brain heart infusion broth (Becton Dickinson, USA). Other bacteria strains were grown in nutrient broth (Becton Dickinson, USA) with aeration at $37^{\circ} \mathrm{C}$.

\section{Antibacterial screening}

The agar diffusion method was employed to determine the antibacterial activity of the essential oil [24]. Briefly, sterile 8-mm paper discs were individually impregnated with $25 \mu \mathrm{l}$ of the essential oil and placed on the solid media plates, which had been surface spread with the tested bacteria $\left(2 \times 10^{8} \mathrm{CFU} / \mathrm{ml}\right)$. To test the effects of oil vapor on the antibacterial activity, the discs containing the oil were placed inside the upper lids of petri dishes. Plates were incubated at $37^{\circ} \mathrm{C}$ for $24 \mathrm{hr}$ and the inhibition zones were measured against bacterial strains tested.

\section{DPPH radical scavenging activity}

Radical scavenging activity was determined using DPPH as a free radical by the method described in the literature [13] with some modifications. This spectroscopic assay uses the stable radical DPPH as a reagent. Briefly, $200 \mu \mathrm{l}$ of various concentrations of sample was added to $50 \mu \mathrm{l}$ of DPPH 
solution (0.15 $\mathrm{mM}$ in methanol) in a 96-well microtiter plate. The sample was dissolved in methanol and used. After $30 \mathrm{~min}$ incubation in the dark at room temperature, the decrease in absorbance was measured at $517 \mathrm{~nm}$. Methanol was used as blank solution, and DPPH solution without any essential oil served as control. BHT, BHA, and ascorbic acid were used as synthetic references. Reduction of DPPH radical in percent $(R \%)$ was calculated in following way:

$$
R \%=\left(\mathrm{A}_{\text {blank }}-\mathrm{A}_{\text {sample }} / \mathrm{A}_{\text {blank }}\right) \times 100,
$$

where $A_{\text {blank }}$ is the absorbance of the control reaction (containing all reagents except the test sample), and $\mathrm{A}_{\text {sample }}$ is the absorbance of the test sample. Tests were carried out in triplicate. For the final results, $\mathrm{RC}_{50}$ values (the concentrations required for $50 \%$ reduction of DPPH $(0.15 \mathrm{mM})$ at $30 \mathrm{~min}$ after starting the reaction) were calculated from the absorbance diminished by $50 \%$. The experiment was performed in triplicate.

\section{ABTS radical scavenging activity}

The antiradical activity using ABTS was measured by ABTS cation decolourisation assay method, as described by Re et al. [16]. Briefly, ABTS radical cation was freshly prepared by mixing $14 \mathrm{mM}$ ABTS with an equal volume of 4.95 $\mathrm{mM}$ potassium persulfate and kept for $24 \mathrm{hr}$ in dark at room temperature. This ABTS radical cation solution was used for the assay after dilution in phosphate buffer saline (PBS) appropriately. To $50 \mu \mathrm{l}$ of various concentration of sample, $150 \mu \mathrm{l}$ of ABTS radical solution was added. After $1 \mathrm{~min}$ incubation at room temperature, the absorbance was measured at $732 \mathrm{~nm}$. Methanol was used as blank solution, and ABTS solution without any essential oil served as control. Trolox was used as reference synthetic antioxidant compound. The experiment was performed triplicate. Reduction of ABTS radical in percent $(R \%)$ and $R C_{50}$ value were calculated the same as described in DPPH radical assay.

\section{Statistical analysis}

All the experiments were performed three to five times. Data are expressed as the mean \pm standard error of the mean (SEM) or SD. A significant difference from the respective controls for each experimental test condition was assessed using Student's $t$ test for each paired experiment. A $P$-value of $<0.05$ was regarded as indicating a statistical significance.

\section{Results and Discussion}

\section{Chemical composition of the essential oil}

Tea tree essential oil tested in this study was analyzed using GC-MS to identify its major components. Total ion chromatography of the oils revealed 24 significant peaks (Fig. 1). We analyzed the mass spectrum of each peak, followed by a search of the library of mass spectra of known chemicals. Authentic standard substances for its candidate were also analyzed using GC-MS under the same condition as in the oil analysis and the results were compared. The result of the tea tree oil is shown in Table 1 . The oil predominantly contained $\beta$-terpinene (20.87\%), $\alpha$-pinene $(17.60 \%)$, p-cymene $(11.23 \%), 3$-carene $(10.40 \%)$, trans-anethole $(8.47 \%)$, limonene (4.65\%), 2,4(10)-thujadien (2.86\%), $\beta$-bourbonene $(2.79 \%), \quad \gamma$-terpinene $(2.44 \%)$ and trans-sabinene hydrate (2.04\%).

Tea tree essential oil has been widely used for its strong antibacterial activity, however, supporting reports about its biological activities and composition has not been clearly known. There are several reports about the major composition of the tea tree oil and Mori et al. [14] has been reported that terpinens (terpinen-4-ol, $\gamma$-terpinens, $\alpha$-terpinene) are the major component of commercial tea tree oils even though the amount in each sample differed. Shabir [19] has also been identified terpinen-4-ol as the major component of pure tea tree oil by GC-FID assay. On the other hand,

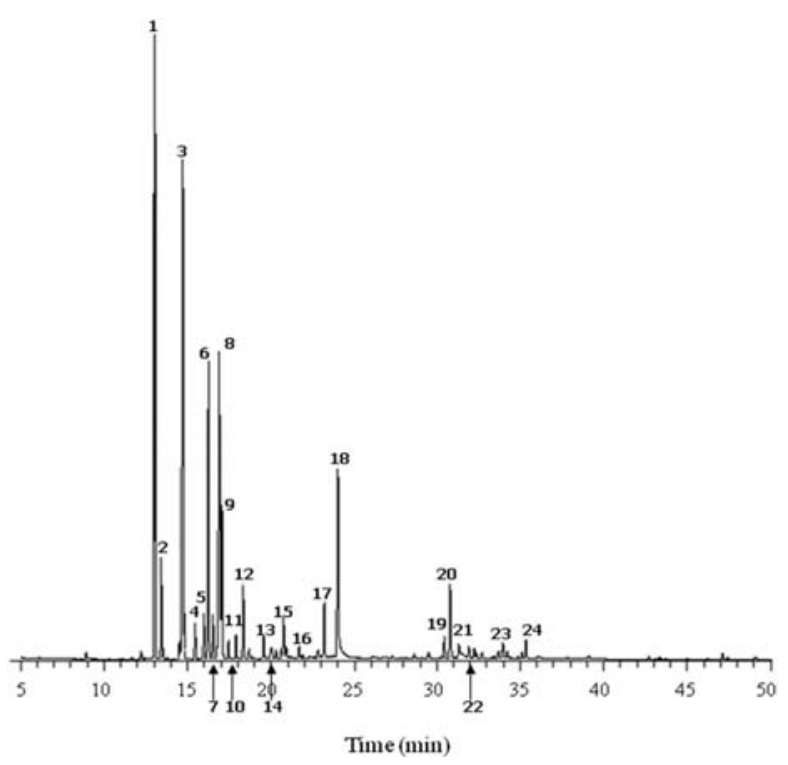

Fig. 1. Total ion current chromatograms of tea tree essential oil obtained by GC-MS analysis. The numbers refer to those in Table 1. 
Table 1. Main components (\%) detected by GC-MS in the tea tree essential oil

\begin{tabular}{cccc}
\hline No. & Compound & $\begin{array}{c}\mathrm{RT}^{\mathrm{a})} \\
(\mathrm{min})\end{array}$ & $\begin{array}{c}\text { Tea tree oil } \\
(\%)^{\mathrm{b})}\end{array}$ \\
\hline 1 & $\alpha$-Pinene & 13.05 & 17.60 \\
2 & $2,4(10)$-Thujadien & 13.42 & 2.86 \\
3 & $\beta$-Terpinene & 14.72 & 20.87 \\
4 & $\beta$-Pinene & 15.45 & 1.04 \\
5 & $\alpha$-Thujene & 15.98 & 1.51 \\
6 & 3-Carene & 16.26 & 10.40 \\
7 & $\alpha$-Terpinene & 16.52 & 1.32 \\
8 & p-Cymene & 16.89 & 11.23 \\
9 & Limonene & 17.06 & 4.65 \\
10 & cis-Ocimene & 17.46 & 0.57 \\
11 & Thujol & 17.89 & 0.81 \\
12 & $\gamma$-Terpinene & 18.33 & 2.44 \\
13 & $\alpha$-Terpinolene & 19.56 & 0.85 \\
14 & 2- $\beta$-pinene & 20.05 & 0.77 \\
15 & Thujone & 20.75 & 1.44 \\
16 & 4 -Thujen-3-ol & 21.68 & 0.51 \\
17 & trans-Sabinene hydrate & 23.19 & 2.04 \\
18 & trans-Anethole & 24.00 & 8.47 \\
19 & Germacrene-D & 30.46 & 0.76 \\
20 & $\beta$-Bourbonene & 30.80 & 2.79 \\
21 & Humulen-(v1) & 31.31 & 0.73 \\
22 & a-Amorphene & 31.92 & 0.51 \\
23 & Aromadendrene & 33.97 & 0.75 \\
24 & (+)-Sativen & 35.35 & 0.74 \\
\hline
\end{tabular}

a) Percentages obtained by MSD peak area normalization.

b) Retention time

Russell and Southwell [17] showed that leaves of M. alterifolia contained low concentration of terpinen-4-ol in the early stage of seeding growth and its concentration rose by the time its mature. Our result is not consistent with these previous reports of tea tree oil, thus further analysis using various commercial tea tree oils and different origins are needed for validation of its major constituents.

\section{Effect of the essential oil on human fibroblast cells}

The result of cytotoxicity of the tea tree oil on the CCD-986SK human fibroblast cells is shown in Fig. 2. The essential oil did not affect the cell viability $1 \mathrm{~h}$ after the cell treatment for both concentrations, although the high concentration of the oil decreased cell viability with no significance. After $3 \mathrm{~h}$ of cells incubation with the essential oil, the 1.0\% $(\mathrm{v} / \mathrm{v})$ and $5.0 \%(\mathrm{v} / \mathrm{v})$ oil significantly decreased cell viabilities to $60.6 \pm 3.68 \%$ and $17.8 \pm 3.22 \%$, respectably. The viabilities were decreased further after $6 \mathrm{hr}$ and $24 \mathrm{hr}$ of cells incubation with the oils, and the higher concentration of the

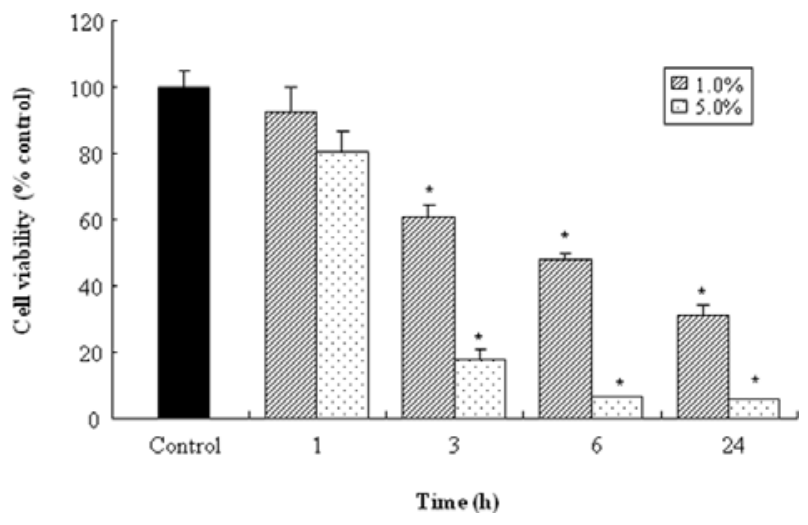

Fig. 2. Effects of tea tree oil on the viability of CCD-986SK human fibroblast cells. Cells were treated with the oil for 24 hr. ${ }^{*} p<0.01$ compared to control.

oil showed strong cytotoxic effect.

While its biological activities such as antimicrobial and inflammatory effects are increasingly well characterized, relatively limited data are available on the safety and toxicity of the oil. Soderberg et al. [21] have reported that the essential oil showed little toxicity in concentrations lower than $100 \mu \mathrm{g} / \mathrm{ml}$ but higher concentrations than this caused a rapid decline in human epithelial and fibroblast cells viabilities.

\section{Free radical-scavenging activity}

Free radical-scavenging capacity was evaluated by measuring the scavenging activity of the essential oil on DPPH and ABTS radicals. DPPH radical scavenging activities of the tea tree oils and of references at $5 \mu \mathrm{g} / \mathrm{ml}$ are presented in Fig. 3(A). The essential oil reduced the DPPH radical formation in a dose-dependent manner. The scavenging activities of the oil were $13.7 \pm 0.79,25.0 \pm 0.15,41.9 \pm 0.14,89.7 \pm 1.20$, $91.3 \pm 2.1$ at $1.0,1.7,2.5,5.0,10.0 \%(\mathrm{v} / \mathrm{v})$ oil concentrations, respectively. Among the references at $5 \mu \mathrm{g} / \mathrm{ml}$, ascorbic acid (96.5 $\pm 2.31 \%)$ showed higher DPPH radical-scavenging activity than BHA $(70.3 \pm 7.57 \%)$ or BHT $(20.2 \pm 0.92 \%)$, and it was almost equal to those of $5.0 \%$ and $10.0 \%$ oil. Moreover, the radical scavenging activities of the oil (1.0 to $10.0 \%)$ were comparable with or stronger than that of $5 \mu \mathrm{g} / \mathrm{ml}$ BHT. ABTS radical scavenging activity of the essential oil was also investigated with various oil concentrations. The oil also reduced the ABTS radical formation in a concentrationdependent manner. As shown in Fig. 3(B), although the ABTS-scavenging activity of the oil were less effective than that of $0.14 \mathrm{mM}$ trolox $(94.7 \pm 0.06 \%)$, the activities of the oil at $5.0 \%(88.3 \pm 0.31 \%)$ and $10.0 \% \quad(92.8 \pm 0.38 \%)$ exhibited strong scavenging effects. The values of $\mathrm{RC}_{50}$ of the essential 
(A)

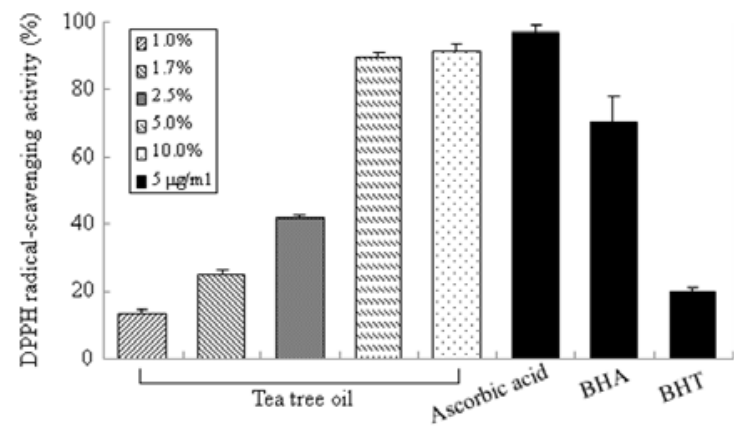

(B)

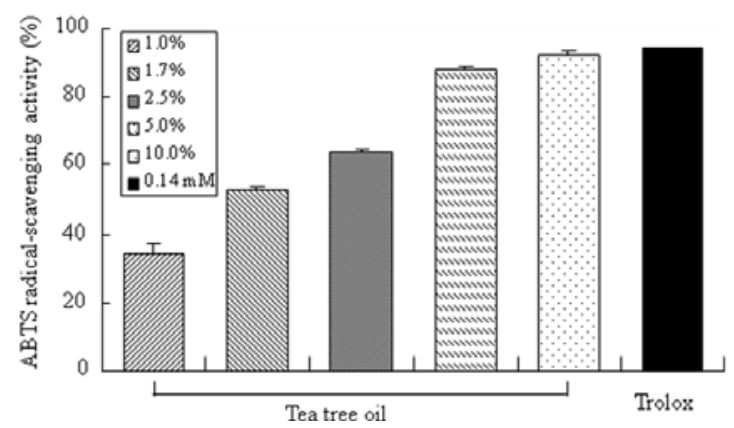

Fig. 3. Free radical-scavenging activities of tea tree essential oil and references. Essential oil was diluted in methanol to $1.0 \%, 1.7 \%, 2.5 \%, 5.0 \%, 10.0 \%$ and the references were used at $5 \mu \mathrm{g} / \mathrm{ml}$ for DPPH (A) and $0.14 \mathrm{mM}$ trolox for ABTS system (B).

oil and the references against DPPH and ABTS radicals were determined as shown in Table 2. The tea tree essential oil exhibited slightly lower $\mathrm{RC}_{50}$ value against ABTS radicals $(1.6 \pm 0.02 \%)$ than DPPH radicals $(2.6 \pm 0.29 \%)$, and ascorbic acid showed lowest $\mathrm{RC}_{50}$ value of $2.0 \pm 0.13 \mu \mathrm{g} / \mathrm{ml}$ against $\mathrm{DPPH}$ radicals among the references. The $\mathrm{RC}_{50}$ value of trolox was $73.5 \pm 0.59 \mu \mathrm{M}$ under the condition.

There are several reports about antioxidant activity of tea tree oil (M. alternifolia), however, the results were varied. The DPPH scavenging activity of the oil $(1 \%, v / v)$ in our study was about $14 \%$ which is much lower than that of the Kim et al. [10] whose data demonstrated that the tea tree oil $(1 \%$, v/v) showed $80 \%$ activity on DPPH radicals. However, Lis-Balchin et al. [11] has demonstrated that essential oil of the Australian tea tree (M. alternifolia) showed no antioxidant
Table 2. $\mathrm{RC}_{50}$ values of tea tree essential oil and reference antioxidants

\begin{tabular}{lcc}
\hline \multirow{2}{*}{ Sample } & \multicolumn{2}{c}{$\mathrm{RC}_{50}$ value $(\%)^{\mathrm{a})}$} \\
\cline { 2 - 3 } & DPPH scavenging & ABTS scavenging \\
\hline Tea tree oil & $2.6 \pm 0.29$ & $1.6 \pm 0.02$ \\
Ascorbic acid $^{\text {c) }}(\mu \mathrm{g} / \mathrm{ml})$ & $2.0 \pm 0.13$ & - \\
BHA $^{\text {c) }}(\mu \mathrm{g} / \mathrm{ml})$ & $3.7 \pm 0.60$ & - \\
BHT $^{\text {c) }}(\mu \mathrm{g} / \mathrm{ml})$ & $39.3 \pm 1.11$ & - \\
Trolox $^{\text {d }}(\mu \mathrm{M})$ & - & $73.5 \pm 0.59$ \\
\hline
\end{tabular}

${ }^{a)}$ Concentration required for $50 \%$ reduction of DPPH $(0.15 \mathrm{mM})$ or ABTS $(7 \mathrm{mM})$ radicals.

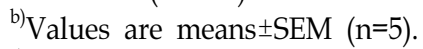

${ }^{c}$ Standard compound for DPPH assay.

${ }^{\mathrm{d})}$ Standard compound for ABTS assay.

activity, while the New Zealand Manuka and Kanuka oils had consistent antioxidant activity. These differences could be due to a difference in chemical constituents of the oils.

\section{Antibacterial activity}

The tea tree essential oil was tested for antibacterial activity using paper disc method against 6 bacterial strains, including Gram-negative bacteria such as A. baumannii, E. coli, $V$. parahaemolyticus; Gram-positive bacteria such as $S$. aureus, S. mutans, L. monocytogenes. As can be seen in Table 4, all the Gram-negative bacterial strains showed more sensibility to the essential oil than the Gram-positive strains except $S$. aureus. The directly contacted oil $(25 \mu \mathrm{l})$ possessed high inhibitory effects $(31 \pm 2.0,30 \pm 6.1,30 \pm 2.9 \mathrm{~mm})$ against $S$. aureus, A. baumannii and E. coli, respectively, however, when comparing the effects of gentamycin the oil was most sensitive to $V$. parahaemolyticus with 3-fold higher inhibitory effect than the reference. On the other hand, the vapor phase of the essential oil against $S$. aureus exhibited strongest inhibitory effect $(35 \pm 0.7 \mathrm{~mm})$ even slightly higher than the contact phase. The inhibitory effects of the oil vapor phase showed $60.0,66.7,55.3,68.8,44.4 \%$ of the contact phase against A. baumannii, E. coil, V. parahaemolyticus, S. mutans and L. monocytogenes, respectively. Thus, the essential oil was

Table 3. Bacterial strains used for the disc diffusion assay

\begin{tabular}{cl}
\hline \multicolumn{1}{c}{ Strain (Group) } & \multicolumn{1}{c}{ Media for cultivation } \\
\hline Acinetobacter baumannii KCTC $2508(\mathrm{Gram}-)$ & Nutrient Agar Broth \\
Escherichia coli KCCM $43888(\mathrm{Gram}-)$ & Nutrient Agar Broth \\
Vibrio parahaemolyticcus KCCM $11965(\mathrm{Gram}-)$ & Nutrient Agar Broth \\
Staphylococcus aureus KCTC $1916(\mathrm{Gram}+)$ & Tryptic Soy Broth \\
Streptococcus mutans KTCT $3065(\mathrm{Gram}+)$ & Brain Heart Infusion Broth \\
Listeria monocytogenes KCTC $3710(\mathrm{Gram}+)$ & Brain Heart Infusion Broth \\
\hline
\end{tabular}


Table 4. Antibacterial effect of tea tree essential oil using disc diffusion method against bacterial strains

\begin{tabular}{|c|c|c|c|c|}
\hline \multirow[b]{2}{*}{ Strain } & \multicolumn{2}{|c|}{ Contact ${ }^{1)}$} & \multicolumn{2}{|c|}{ Vapor ${ }^{2)}$} \\
\hline & $\begin{array}{c}\text { Tea tree } \\
\text { oil }^{3)}\end{array}$ & Gentamycin $^{4)}$ & $\begin{array}{c}\text { Tea tree } \\
\text { oil }^{3)}\end{array}$ & Gentamycin $^{4)}$ \\
\hline A. baumannii & $30 \pm 6.1^{5)}$ & $12 \pm 0.6$ & $18 \pm 1.4$ & $\mathrm{NA}^{6)}$ \\
\hline E. coli & $30 \pm 2.9$ & $12 \pm 0.6$ & $20 \pm 0.7$ & NA \\
\hline V. parahaemolyticcus & $27 \pm 0.6$ & $9 \pm 1.7$ & $16 \pm 1.4$ & NA \\
\hline S. aureus & $31 \pm 2.0$ & $25 \pm 0.6$ & $35 \pm 0.7$ & NA \\
\hline S. mutans & $16 \pm 3.2$ & $18 \pm 1.0$ & $11 \pm 0.4$ & NA \\
\hline L. monocytogenes & $18 \pm 3.5$ & $19 \pm 0.6$ & $8 \pm 0.6$ & NA \\
\hline
\end{tabular}

${ }^{1)}$ Disc conraining the oil was placed directly on agar plate.

${ }^{2)}$ Disc containing the oil was placed inside the upper lid of petri dish.

${ }^{3)}$ Tested at a concentration of $25 \mu \mathrm{l} /$ disc.

${ }^{4)}$ Tested at a concentration of $25 \mu \mathrm{g} /$ disc.

${ }^{5)}$ Values are diameters of clear zone of inhibition $(\mathrm{mm})$ including disc diameter of $8 \mathrm{~mm}$.

${ }^{6)} \mathrm{NA}$, not active.

most effective for inhibition of $S$. aureus in direct contact as well as the vapor phase.

Tea tree oil has been shown to have strong bactericidal activity against methicilin-resistant Staphylococcus aureus (MRSA) [8,12,15,20], and its antimicrobial action tested against E.coli, S. aureus, and C. albicans is most likely through the ability to disrupt the permeability barrier of cell membrane structures and the accompanying loss of chemiosmotic control at minimum inhibitory levels [5]. It has been reported that the antimicrobial activity of $M$. alternifolia oil was due to its high content of terpinene-4-ol [22], and terpinene-4-ol exhibited greater antimicrobial activity than tea tree oil tested by time-kill studies [12]. The tea tree oil used in this study did not contain terpinene-4-ol, however, it exhibited strong antiradical and antimicrobial activities compare to other herb essential oils such as lavender, rosemary, and peppermint under the same conditions (data not shown). To make clear the most responsible component in tea tree oil, the analysis of antimicrobial activity using its main compounds are under investigation.

\section{Acknowledgements}

This work was supported by Korea Institute of Industrial Technology Evaluation and Planning (ITEP) and Ministry of Commerce, Industry and Energy (MOCIE) through the Center for Traditional Microorganism Resources (TMR) at Keimyung University, Korea.

\section{References}

1. Brophy, J. J., N. W. Davies, I. A. Soulthwell, I. A. Stiff and L. R. Williams. 1989. Gas chromatographic quality control for oil of Melaleuca terpinene-4-ol type (Australian tea tree). J. Agric. Food Chem. 37, 1330-1335.

2. Carson, C. F., B. D. Cookson, H. D. Farrelly and T. V. Riley. 1995. Susceptibility of methicillin-resistant Staphylococcus aureus to the essential oil of Melaleuca alternifolia. J. Antimicrob. Chemother. 35, 421-424.

3. Carson, C. F. and T. V. Riley. 1995. Antimicrobial activity of the major components of the essential oils of Melaleuca alternifolia. J. App. Bact. 78, 264-269.

4. Carson, C. F., K. A. Hammer and T. V. Riley. 2006. Melaleuca alternifolia (Tea Tree) oil: a review of antimicrobial and other medicinal properties. Clin. Microbiol. Rev. 19, 50-62.

5. Cox, S. D., C. M. Mann, J. L. Markham, H. C. Bell, J. E. Gustafson, J. R. Warmington and S. G. Wyllie. 2000. The mode of antimicrobial action of the essential oil of Melaleuca alternifolia (tea tree oil). J. Appl. Microbiol. 88, 170-175.

6. Evandri, M. G., L. Battinelli, C. Daniele, S. Mastrangelo, P. Bolle and G. Mazzanti. 2005. The antimutagenic activity of Lavandula angustifolia (lavender) essential oil in the bacterial reverse mutation assay. Food Chem. Toxicol. 43, 1381-1387.

7. Halcón, L. and K. Milkus. 2004. Staphylococcus aureus and wounds: a review of tea tree oil as a promising antimicrobial. Am. J. Infect Control 32, 402-408.

8. Harkenthal, M., J. Reichling, H. K. Geiss and R. Saller. 1999. Comparative study on the in vitro antibacterial activity of Australian tea tree oil, cajuput oil, niaouli oil, manuka oil, kanuka oil, and eucalyptus oil. Pharmazie. 54, 460-463.

9. Jones, M. R., E. J. Julia and R. Victor. 1992. Steam distillation of tea tree (Melaleuca alternifolia) oil. J. Sci. Food Agric. 58, 49-53.

10. Kim, H. J., F. Chen, C. Wu, X. Wang, H. Y. Chung and Z. Jin. 2004. Evaluation of antioxidant activity of Australian tea tree (Melaleuca alternifolia) oil and its components. J. Agric. Food Chem. 52, 2849-2854.

11. Lis-Balchin, M., S. L. Hart and S. G. Deans. 2000. Pharmacological and antimicrobial studies on different tea-tree oils (Melaleuca alternifolia, Leptospermum scoparium or Manuka and Kunzea ericoides or Kanuka), originating in Australia and New Zealand. Phytother. Res. 14, 623-629.

12. Loughlin, R., B. F. Gilmore, P. A. McCarron and M. M. Tunney. 2008. Comparison of the cidal activity of tea tree oil and terpinen-4-ol against clinical bacterial skin isolates and human fibroblast cells. Lett. Appl. Microbiol. 46, 428-433.

13. Moreno, M. I., M. I. Isla, A. R. Sampietro and M. A. Vattuone. 2000. Comparison of the free radical-scavenging activity of propolis from several regions of Argentina. J. Ethnophamacol. 71, 109-114.

14. Mori, M., N. Ikeda, Y. Kato, M. Minamino and K. Watabe. 2002. Quality evaluation of essential oils. Yakugaku Zasshi 122, 253-261.

15. Park, H., C. H. Jan, Y. B. Cho and C. H. Choi. 2007. 
Antibacterial effect of tea-tree oil on methicillin-resistant Staphylococcus aureus biofilm formation of the tympanostomy tube: an in vitro study. In Vivo 21, 1027-1030.

16. Re, R., N. Pellegrini, A. Proteggente, A. Pannala, M. Yang and C. Rice-Evans. 1999. Antioxidant activity applying an improved ABTS radical cation decolorization assay. Free Radic. Biol. Med. 26, 1231-1237.

17. Russell, M. and I. Southwell. 2002. Monoterpenoid accumulation in Melaleuca alternifolia seedlings. Phytochemistry 59, 709-716.

18. Russell, M. F. and I. A. Southwell. 2003. Monoterpenoid accumulation in 1,8-cineole, terpinolene and terpinen-4-ol chemotypes of Melaleuca alternifolia seedlings. Phytochemistry 62, 683-689.

19. Shabir, G. A. 2005. Method development and validation for the GC-FID assay of $p$-cymene in tea tree oil formulation. J. Pharm. Biomed. Anal. 39, 681-684.

20. Sherry, E., H. Boeck and P. H. Warnke. 2001. Percutaneous treatment of chronic MRSA osteomyelitis with a novel plant-derived antiseptic. BMC Surg. 1, 1-3.

21. Söderberg, T. A., A. Johansson and R. Gref. 1996. Toxic effects of some conifer resin acids and tea tree oil on human epithelial and fibroblast cells. Toxicology 107, 99-109.

22. Southwell, I. A. 1988. Australian tea tree oil of Melaleuca terpinene-4-ol type. Chem. Aust. 55, 400-402.

23. Tong, M. M., P. M. Altman and R. S. Barnetson. 1992. Tea tree oil in the treatment of tinea pedis. Australas. J. Dermatol. 33, 145-149.

24. Traub, W. H. and B. Leonhard. 1997. Susceptibility of Moraxella catarrhalis to 21 antimicrobial drugs: validity of current NCCLS criteria for the interpretation of agar disk diffusion antibiograms. Chemotherapy 43, 159-167.

25. van de Loosdrecht, A. A., E. Nennie, G. J. Ossenkoppele, R. H. Beelen and M. M. Langenhuijsen. 1991. Cell mediated cytotoxicity against $\mathrm{U} 937$ cells by human monocytes and macrophages in a modified colorimetric MTT assay. A methodological study. J. Immunol. Methods 141, 15-22.

\section{초록 : 티트리 에센셜오일의 생물활성 및 주요 성분 분석}

양선아 · 전상경 ${ }^{1} \cdot$ 이은정 ${ }^{1} \cdot$ 임남경 ${ }^{1} \cdot$ 정지영 ${ }^{2} \cdot$ 이인선 ${ }^{1} *$

(계명대학교 TMR 센터, ${ }^{1}$ 계명대학교 식품 가공학과, ${ }^{2}$ (주)멘텍)

티트리 에센셜 오일은 호주 원주민들의 전통적인 피부 소독제나 치료제로 널리 사용되어 왔으며, 항균효과와 주요성분 등 많은 보고가 있으나 추출 방법이나 사용 부위 등에 따라 효능의 차이를 보인다. 본 연구에서는 아로 마테라피 등에 현재 많이 이용되고 있는 시판 티트리 오일의 성분과 효능을 평가하여, 다른 에센셜 오일과의 비 교 이용을 용이하게 하고자 하였다. 티트리 오일의 주요성분은 GC-MS 분석에 의하여 $\beta$-terpinene $(20.87 \%), \alpha$ pinene $(17.60 \%)$, p-cymene (11.23\%), 3-carene $(10.40 \%)$, trans-anethole $(8.47 \%)$, limonene $(4.65 \%)$ 으로 밝혀졌으 며, $5 \%$ 이하의 농도에서 3 시간 미만까지는 피부세포에 독성이 없었다. 오일의 라디컬 소거능을 알아본 결과, $\mathrm{DPPH}$ 와 ABTS의 양라디컬에 대하여 강한 소거능을 나타내어 강한 항산화능을 시사했다. 또한, 오일의 direct contact와 vapor-phase의 항균활성을 disc diffusion법으로 스크리닝 한 결과, direct contact 활성의 경우 그람음 성균에 대하여 높은 활성을 나타내었으며, vapor는 S. aureus에 대하여 강한 효과를 나타내었다. 본 연구에서 실 제 많이 사용되는 티트리 오일의 성분과 생물활성을 측정함으로써 허브 오일들의 정확한 선택과 활용을 위한 기본적인 결과를 얻었다. 